\section{B A Institute of \\ YK Business Administration \\ 六下 \\ Karachi \\ Leadership and Ideas for Tomorrow}

Business Review

Volume 16 Issue 2 July-December 2021

2022

\title{
Linking online business education and academic excellence: outbreak of COVID-19 pandemic
}

\author{
Muhammad Rafiq \\ Superior University, Lahore \\ Shumaila Naz \\ Iqra University, Karachi \\ Saif Maqbool \\ National University of Computer and Emerging Sciences
}

Follow this and additional works at: https://ir.iba.edu.pk/businessreview

Part of the Business Administration, Management, and Operations Commons, Operations and Supply Chain Management Commons, and the Organizational Behavior and Theory Commons

\section{(c) (9)}

This work is licensed under a Creative Commons Attribution 4.0 International License.

\section{Recommended Citation}

Rafiq, M., Naz, S., \& Maqbool, S. (2022). Linking online business education and academic excellence: outbreak of COVID-19 pandemic. Business Review, 16(2), 44-59. Retrieved from https://doi.org/10.54784/ $1990-6587.1410$

This article is brought to you by iRepository for open access under the Creative Commons Attribution 4.0 License and is available at https://ir.iba.edu.pk/businessreview/vol16/iss2/3. For more information, please contact irepository@iba.edu.pk. 


\title{
Linking Online Business Education and Academic Excellence: Outbreak of COVID-19 Pandemic
}

\author{
Muhammad Rafiq · Shumaila Naz • Saif \\ Maqbool
}

\begin{abstract}
The outburst of COVID-19 epidemic has enforced the higher education sector to revamp customary mode of teaching and assessing students learning. This study is a portrayal of online education and intended to critically examine how online education during COVID-19 fostered a combination of favorable and unfavorable outcomes which might disrupt and redesign academic routine process. Data were collected from professors, associate professors and rectors affiliated with higher education system through focused group discussions and semi-structured interviews. The interpretivism paradigm analysis was performed to examine the data using qualitative methodology. This study delivers a comprehensive review of enduring online education mode through the lock-down tenure. It outlines details on how quality of education was ensured through online teaching-learning process, E-portal access, self-reliant technological system, online assessment, and quality standards. Findings delineated that higher education sector converted challenge into opportunity without wasting students semester and facilitated them in achieving academic quality, thereby overcoming the continuous academic distortion and subsequently ensuring the renewal of educational procedures. Results also reported numerous challenges faced by teachers and management in delivering quality education. This research refills the existing gap by adding to the literature on online education from the perspectives of key academias concerns during the COVID-19 epidemic. It also provides practical implications to governing bodies and policy makers of higher education sector.
\end{abstract}

Keywords Online Education, Academic Excellence, COVID-19, Educational Transformation, Digital Competence.

Muhammad Rafiq

Superior University

E-mail: m.rafiq@superior.edu.pk

Shumaila Naz

Iqra University Karachi

Saif Maqbool

National University of Computer and Emerging Sciences

(C)Rafiq, M., Naz, S., and Maqbool, S. 2022 
Linking online business education and academic excellence:

\section{Introduction}

An infectious virus, Covid-19, adversely affected all facades of economic activities due to its spread. This pandemic has shaken the world by slowing down economic activities of many sectors and even stopping it altogether. Moreover, the prediction about gross domestic productivity (GDP) was equally abysmal as research shows that it was supposed to decline by more than $10 \%$ (Wang et al 2021). The global education during the pandemic, alongside the pecuniary miserabilist situation, has incurred unrecoverable loss. According to UNESCO statistics, nearly 63 million educationists are affected in almost 165 nations. A total of 990 million learners around the world were affected which makes up $56.6 \%$ of total enrolled learners across 131 country wide closures (Setiawan 2020). Stakeholders raised apprehension about the prolonged closure of education institutes and its effects on learning, assessments, credentials and teaching. They claimed that students result and progress would be prolonged due to the disruption and will also have broader socio-economic impact.

To ensure social distancing in communities and curb the deadly disease, the government of Pakistan imposed smart lock down, which resulted in the shutdown of education institutions. World Health Organization (WHO) avowed Covid-19 as epidemic on 11th March, 2020, which escalated the globe by affecting 185 regions over 2.5 million people, and resulting in 187000 causalities (Cucinotta and Vanelli 2020). Due to continuous spread, most of the countries education, economic and social systems were directly or indirectly maneuvered. The lives of people in Pakistan due to current emergence of Covid-19 coronavirus is impacted directly. The first two cases were reported in Pakistan in late February, 2020 and reached to 14,885 at 29th April, 2020 causing 327 deaths. The recovery rate in Pakistan was $22.2 \%$ while fatality rate reached to $2.1 \%$. The government of Pakistan issued an advisory to Higher Education Institutions (HEIs) to take online classes during Covid-19 spread and permitted instructors to work from home to avoid crowd during classes. Education Technology (EdTech) model was preferred over traditional way of teaching (Alhumaid et al 2020).

As classes shifted online as per decision by government of Pakistan, many HEIs started exploring possibilities of bringing efficient technology to education system to facilitate remote education and learning during the epidemic. Moreover, it is worth mentioning that Moodle, blackboard (teaching apps), Zoom and Microsoft teams softwares were missing in HEIs of Pakistan due to unviability of funds at the start. However, Higher Education Commission has made it mandatory for HEIs to use online mediums of teaching like Skype, YouTube, WhatsApp and Google Hangout for lectures delivery. However, the lack of familiarity with these platforms has stirred online teaching and students assessment and created many uncertainties (Adnan and Anwar 2020).It is well proven fact that without teachers involvement, the endeavour will be unsuccessful, as teachers are the prologist of the teaching system. The studies on barriers of online teaching are under dearth in developing countries although there are plethora of studies in developed nations: FL (shea), Japan (Sutherland), Luxembourg (Stoffregen) and Germany (Sutherland et al 2016; Wagman et al 2016).

Business Review: (2021) 16(2):44-59 
Online tutoring in Pakistan is relatively new concept which got more attention during epidemic. Online teaching platform became mandatory during Covid-19 in developing countries as well and it opened new avenues of teaching and assessment for education support and improvement. The instructors are supposed to adapt to techno-based teaching systems for successful execution of teaching assessments (Molise and Dube 2020). The popularity of online teaching in Pakistan is not at its peak yet. Lack of training opportunities for teachers regarding online teaching and assessment is main reason of unpopularity in Pakistan. However, the lockdown left no choice other than online teaching. Teachers faced many challenges such as an unstable internet connection, lack of access to microphones and other technical equipment (Farooq et al 2020).

As compared to university environment, online teaching and assessment from home has different problems. The university premises provide conducive learning environment and ensures that people have availability of all requisite resources. To rectify the problem, the current research investigates barricades that are confronted by instructors and coaches while teaching in a home environment in Pakistan and ensures appropriate solution of how further universities can use a hybrid model. The intentions of the current paper are to identify the intervening mechanism to improve excellence in academics. Though several studies are available on online teaching opportunities and challenges, this study goes beyond routine inquiry from teachers and students by taking the views of higher authorities such as; Rectors, Assistant Professors, Associate Professors. The research embarks strong implications to the governing establishments and bodies of HEIs who intend to espouse online education and assessment as a continuous mode in the future (Alhumaid et al 2020).

\section{Literature review}

The literature on online teaching and assessment with accordance to Covid19 epidemic situation especially in developing counties like Pakistan is scarce. Hence, it is not easy to conduct a rigorous literature; instead, researchers rely on expert opinion. It is incontestable to say that Covid-19 has put education system in jeopardy without any discrimination round the globe. The challenge is putative by the educational foundations in order to take benefit of asynchronous education that is in the form of digital formats. To veer the teaching pedagogy, the online mechanisms were requiring a modification from traditional or conventional learning to online or digital learning in order to mitigate the Covid-19 damages to education. For Pakistani teachers, adopting the online teaching technology was the major challenge due to short span of time. Additionally, they were required to have the online assessments that added to their problem. According to Joshi et al (2020), online classes during shutdown was an awful teaching experience. To achieve state-of-the-art quality in online classes remained an unrealized dream in Pakistan as reported by (Farooq et al 2020). Additionally, Gujjar et al (2010) also raised apprehensions and stated that the digitalization was divided and infrastructure for online teaching was abrupt in Pakistan. 
Linking online business education and academic excellence:

\subsection{Online education platform}

Currently, the online education and learning during Covid-19 is addressed and explored by numerous researchers who discussed the challenges and problems widely through their forum faced by both, students and teachers. However, the studies on teachers problems are minute although teachers are the key stakeholders of the education system. Furthermore, Nation et al (2020) asserted that teachers in Los Angles are willing to teach online but their resistance is highlighted due to lack of online teaching skills and problems related to time management for online course preparation. Additionally, matching the requirement of students is also unbalanced. Another study by Arora and Srinivasan (2020) talked about internet connectivity problems, lack of interaction, personal touch, interest, awareness, training, and low attendance as primary encounters faced by course facilitators in online teaching process.

Furthermore, Aliyyah et al (2020) denoted the challenges related to training, students engagement and use of fade technology in sustaining academic excellence during epidemic of Coronavirus. The online teaching concerns are related to insufficient resource as network and microphones and configuration of laptops to efficiently convey education. Connectivity is the prime problem discussed by teachers alongside lack of technical assistance during online sessions, bandwidth issues, failure of computer's to work properly and internet stability. Mailizar et al (2020) agreed to the said problems and challenges and further asserted that a number of education institutes have not conducted any training for teachers to teach online and to work remotely by using online platforms. Without clear directions and instructions, HEIs instructed their faculties to teach and disperse lectures from homes. It created troubles for all teachers especially for old teachers who are not familiar with digital technology and are not technically aware of how to conduct online sessions with students (Scherer et al 2019). Remotely managing students was difficult for teachers in most cases. Opening different windows, playing games, eating and drinking during lecture, making noise, playing musing and carrying out disruptive activities during the session were noticed (Farooq et al 2020). The experience of teachers teaching from home was exhausting activity and demotivated them.

The prior studies have identified technology adoption as evolving barriers for teaching. It is normally expected that system level, school-level and teacher-level difficulties have discouraged teachers to learn new technological skills. Barnard et al (2013) noticed that cost and benefit analysis, technology barriers, training, interpersonal barriers and institutional barriers were professed for online teaching in south eastern education system in united states. Furthermore, Baticulon et al (2021) conducted study in Florida on online teaching and found that complexity of program, size of institution and lack training are hidden challenges faced by concerning faculty for effective online teaching.

Lack of time, confidence, belief in benefits of information and technology (ICT, institutional support, and lack of equipment are burning challenges in utilization of modern technology in Oman for online teaching. Moreover, Baticulon et al (2021) identified major barriers for online teaching that includes; technical, cultural, students support, legal, labor management, governance, ge- 
ographic, fiscal and academic. Online format of teaching was resisted by some faculties due their negative attitude towards digital technology, lack of translation of course contents, self-efficacy in computer, lack of technological support, ICT competence and lack of time (Alhumaid et al 2020; Prottas et al 2016; Taylor 2002). The institutional support in provision of time and finance to conduct quality online classes is lacking due to which teachers are demotivated (Taylor 2002). After the extensive literature review and interview with subject experts, the following variables are embedded and identified.

Table 1: Identification of Key Variables

\begin{tabular}{|c|c|c|c|}
\hline $\begin{array}{l}\text { Sr. } \\
\#\end{array}$ & $\begin{array}{l}\text { Key Issues/ } \\
\text { factors }\end{array}$ & Variables & References \\
\hline 1 & $\begin{array}{l}\text { Online teaching } \\
\text { and assessments }\end{array}$ & V1 & $\begin{array}{l}\text { Aliyyah et al (2020); Joshi } \\
\text { et al (2020); Prottas et al } \\
(2016) \text {; Taylor (2002) }\end{array}$ \\
\hline 2 & $\begin{array}{l}\text { Institutional sup- } \\
\text { port }\end{array}$ & $\mathrm{V} 2$ & $\begin{array}{l}\text { ?Joshi et al (2020); Khan et al } \\
\text { (2017); Rizvi et al (2017) }\end{array}$ \\
\hline 3 & $\begin{array}{l}\text { Digital compe- } \\
\text { tence and } \\
\text { technical difficul- } \\
\text { ties }\end{array}$ & V3 & $\begin{array}{l}\text { Cahen and Borini (2020); } \\
\text { Doyumgaç et al (2021); Rajab } \\
\text { et al (2020) }\end{array}$ \\
\hline 4 & $\begin{array}{l}\text { Academic excel- } \\
\text { lence }\end{array}$ & V4 & $\begin{array}{l}\text { Adedoyin and Soykan (2020); } \\
\text { Baber (2020); Sun et al (2020) }\end{array}$ \\
\hline 5 & $\begin{array}{l}\text { An E-learning } \\
\text { paradigm } \\
\text { shift and hybrid } \\
\text { institution }\end{array}$ & V5 & $\begin{array}{l}\text { Adedoyin and Soykan (2020); } \\
\text { Espino-Díaz et al (2020) }\end{array}$ \\
\hline
\end{tabular}

\section{Methodology}

Under qualitative research design, Interpretative Phenomenological Analysis (IPA) was deployed in the present study. IPA intends to observes and appreciate on the whole about the individuals experience of a certain concept. Alase (2017) pointed out that the IPA facilitates in taking deep insight of the respondents views and unfolding it rather than narrating and extracting from grounded preestablished theories and already tested variables. In Interpretative Phenomenological Analysis, the focus group discussion has been subjective in nature which creates a chance for the researchers to comprehend the observations of the members to which they themselves experienced by engaging in a precise segment of an incident. This study collected data from professors, associate professors, and rectors who are associated with academia, through semi-structured interviews and focused-group discussions.

Interpretative phenomenological analysis submits elucidations of the opinions and interpretation of real experiences of the interviewee. Smith and Osborn (2015) precisely stated that it may be employed in a dramatic condition whereby the study has small sample size though demands detailed investigation of phenomenon. In this research, the IPA is used to investigate the obstacles en- 
countered during online education and evaluation after the wake of COVID-19 where imposed lockdown condition had forced instructors to continue teaching and assessing students in their homes. The ISM process consists of:

1) Enlist the key latent constructs such as institutional support, use of digitalization and online teaching support.

2) Relationship between variables is identified by using ISSM.

3) Reachability Matrix is made by converting ISSM.

4) Transitivity is tested in next step.

5) Model levels are derived by using reachability matrix.

6) Relationship is translated and an ISM model is drawn.

7) The inconsistencies are reviewed and is revised consequently.

The structural diagram is portrayed in figure 1 .

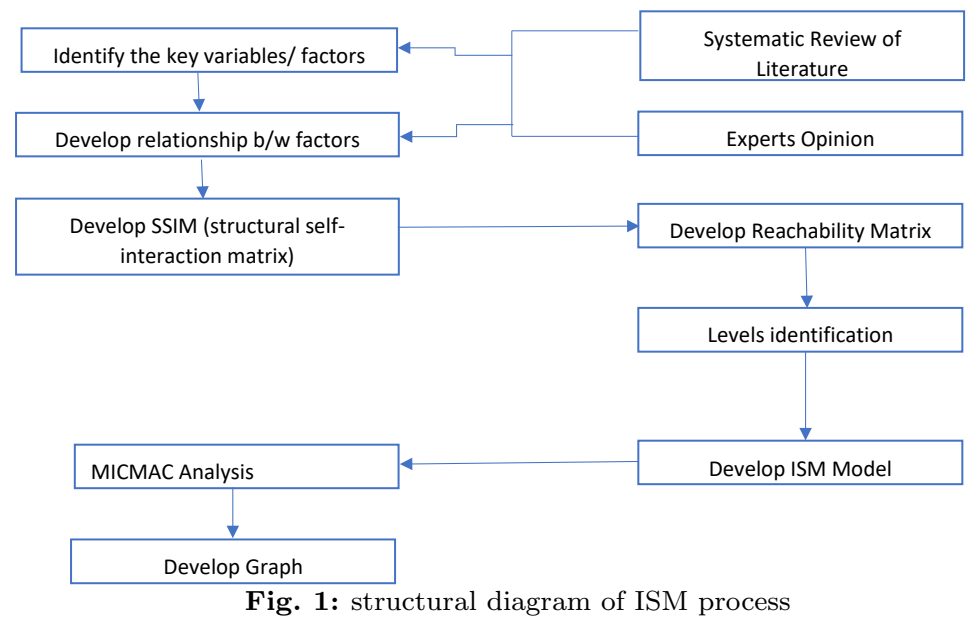

\subsection{Sampling}

The unit of analysis of the extant study were the teachers teaching in the public and private sector universities of Pakistan. There are total 177 universities operating in Pakistan. 103 universities are working at public level and 74 at private level as degree awarding institute (DAIs). Emails were sent and phone calls were made to contact and receive agreement and confirmation from teachers affiliated with various universities. Request was made to the interested respondents for written consent and submission of the ethics approval statement for registering their willingness in the study. In total, 21 teachers (16 teachers from private sector and 5 from public sector) registered for their participation in the study who were experiencing online teaching in home settings during COVID-19 epidemic. 


\subsection{Data collection}

The data was collected through in-depth interviews by using semi-structured technique from teachers and rectors to gather information about the difficulties confronted during online assessments and teachings. No boundary or limit was predetermined during open-ended questions for interview. To check the reliability and validity, the researcher got help of six experts relevant to the field and suggestions were incorporated as per experts opinion. The construct validity was confirmed by availing the services of six teachers who were not part of the study. The interviews were done through telephone due to restriction of lockdown and in-person interviews were restrained due to Covid-19. All recordings were recorded in audio clips. The teachers were asked a few questions regarding the in-home home environment settings and what kind of problems they faced. Additionally, they were also asked what type of teaching and assessment support they got from the institute during their teaching. The 60 minutes interview was conducted on average and the timing fluctuated between 40 to 110 minutes.

\section{Results and discussion}

Table 2: Demographics for Respondants

\begin{tabular}{llll}
\hline Respondents & Gender & $\begin{array}{l}\text { Work } \\
\text { Experience }\end{array}$ & Age \\
\hline R1 & M & 4 & $20-29$ \\
R2 & M & 13 & $20-29$ \\
R3 & M & 5 & $30-39$ \\
R4 & M & 3 & $30-39$ \\
R5 & F & 4 & $20-29$ \\
R6 & M & 4 & $20-29$ \\
R7 & M & 7 & $30-39$ \\
R8 & F & 3 & $20-29$ \\
R9 & F & 2 & $20-29$ \\
R10 & M & 4 & $30-39$ \\
R11 & F & 8 & $30-39$ \\
R12 & M & 3 & $30-39$ \\
R13 & F & 7 & $30-39$ \\
R14 & M & 10 & $40-49$ \\
R15 & M & 5 & $30-39$ \\
R16 & M & 4 & $20-29$ \\
R17 & F & 8 & $40-49$ \\
R18 & M & 2 & $20-29$ \\
R19 & M & 6 & $30-39$ \\
\hline
\end{tabular}

ISM methodology believes that for Structural Self Interaction Matrix, hereafter denoted as SSIM, development, experts and academicians opinion are the best way to examine the relationship between variables as it ultimately strengthens the objective(s) of the study. The background and literature of the factors 
was explained to the experts and they were then asked to deliberate the adequacy of concept. V1,V5 are the variables BD VAXO is the rule to define the rules and is explained in detail below. Using table-2, SSIM matrix is designed as following;

\begin{tabular}{|c|c|c|c|c|c|}
\hline & $\mathrm{V} 1$ & $\mathrm{~V} 2$ & V3 & V4 & V5 \\
\hline V1 & 1 & A & V & $\mathrm{X}$ & $\mathrm{V}$ \\
\hline V2 & & 1 & $\mathrm{~V}$ & $\mathrm{O}$ & $\mathrm{V}$ \\
\hline V3 & & & 1 & $\mathrm{~V}$ & $\mathrm{~V}$ \\
\hline V4 & & & & 1 & V \\
\hline V5 & & & & & 1 \\
\hline
\end{tabular}

Fig. 2: SSIM matrix

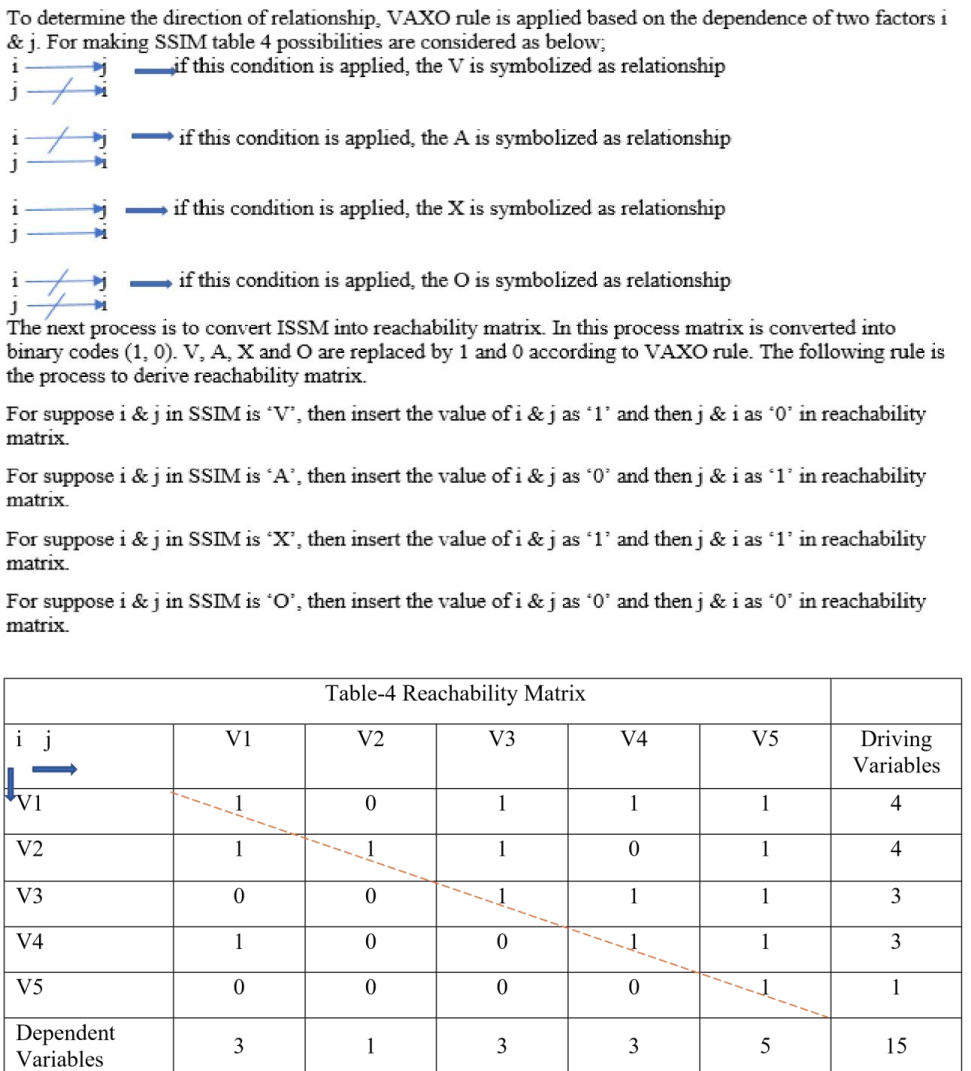

Business Review: (2021) 16(2):44-59 
Identification of levels and transitivity set were the next step to be performed. Reachability columns and intersections are matched in this process as in level-1, best matching is identified and remains at the highest level of hierarchy and so on. In this case, V5 (An E-learning paradigm shift and hybrid institution) is the first level for ISM framework. After that process, V5 is removed in next iteration in both column and we can reach the next level when each level of each factors is obtained. 


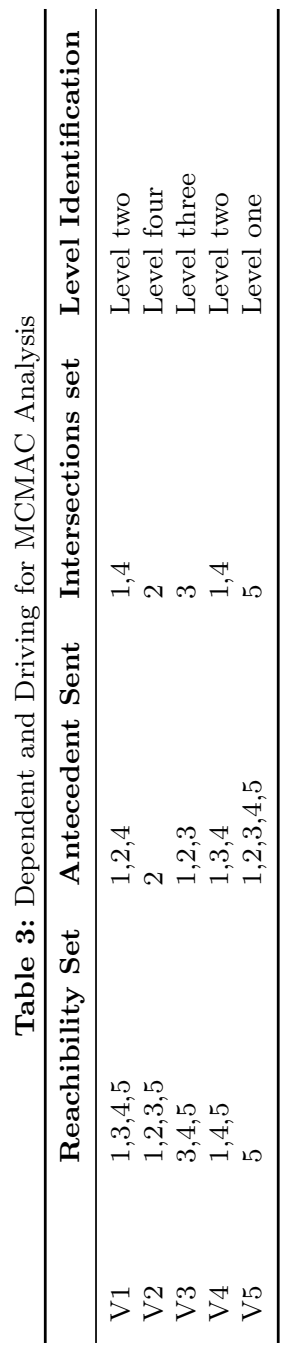

Business Review: (2021) 16(2):44-59 
The structural framework is derived through reachability matrix and through set of intersection. The framework uses the criteria of $i$ to $j$ for demonstration of relationship. The following framework denotes that institutional support, denoted as V2, is the base factor that influences V3, digital competencies and technical difficulties. V2 occupies the basis level in ISM hierarchy, hence is the fundamental influencer to other variables. V5, An E-learning paradigm shift and hybrid institution in ISM framework is denoted as dependent factor that receives influence from all factors. Furthermore, V5 is the factor that has no influence on other variables.

The barriers are classified by utilizing the MICMAC analysis. For classification

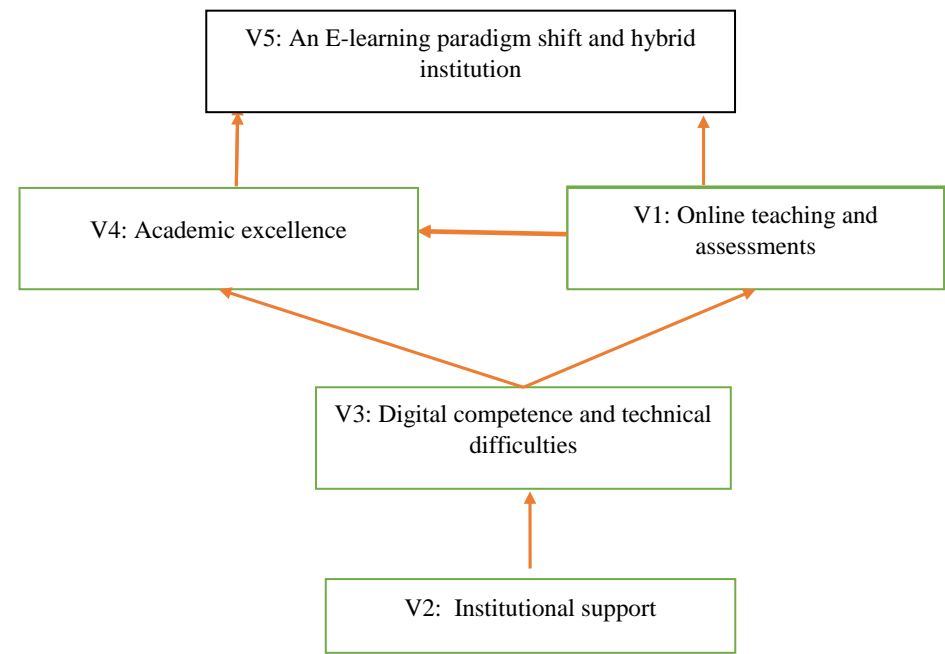

Fig. 3: ISM Model level identification

cross-impact matrix is applied in MICMAC. It has basically two powers;

1) Driving Power on vertical axis and

2) dependent Power on $\mathrm{X}$ axis.

This analysis is further divided into four main categories: autonomous, linkage, independent or driving and dependent factors (Wu and Niu 2017). Table 7 and figure 4 show the depiction of MICMAC analysis of the study.

Figure 4 shows that none of variable falls in autonomous cluster which indicates a weak driving and ultimately dependent power.

1. Variable two Institutional support falls in independent or driving cluster. This indicates that, this variable has capacity to lead other variables. Furthermore, it also indicates organizations need to critically focus on this factor.

2. In this study, three variables (V1, V3 and V4) lies in cluster three named as linking cluster. It shows that these variables have strong bounding with other variables especially with dependent variable. It can be assumed that it is vital to focus on these variables for effective online teaching and coaching.

3. Dependent cluster of the graph showed that V5 is part of this cluster. As it 
Linking online business education and academic excellence:

\begin{tabular}{|c|c|c|c|}
\hline Factors & Variables & $\begin{array}{l}\text { Driving } \\
\text { Variables }\end{array}$ & $\begin{array}{l}\text { Dependent } \\
\text { Variables }\end{array}$ \\
\hline $\begin{array}{l}\text { Online } \\
\text { teaching } \\
\text { and assess- } \\
\text { ments }\end{array}$ & $\mathrm{V} 1$ & 4 & 3 \\
\hline $\begin{array}{l}\text { Institutional } \\
\text { support }\end{array}$ & $\mathrm{V} 2$ & 4 & 1 \\
\hline $\begin{array}{l}\text { Digital com- } \\
\text { petence and } \\
\text { technical } \\
\text { difficulties }\end{array}$ & V3 & 3 & 3 \\
\hline $\begin{array}{l}\text { Academic } \\
\text { excellence }\end{array}$ & V4 & 3 & 3 \\
\hline $\begin{array}{l}\text { An E- } \\
\text { learning } \\
\text { paradigm } \\
\text { shift } \\
\text { and hybrid } \\
\text { institution }\end{array}$ & V5 & 1 & 5 \\
\hline
\end{tabular}

is the dependent variable it is more sensitive in nature and institutions should make strong policies to strengthen this variable.

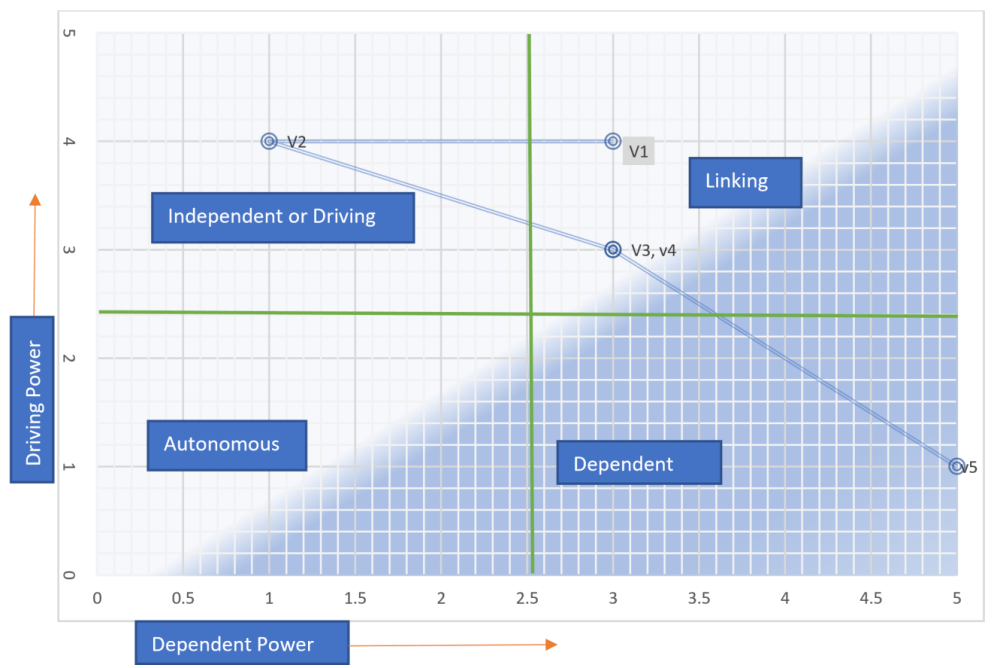

Fig. 4: MICMAC Analysis of the study 


\subsection{Discussion}

Teachers encountered many problems while teaching in the setting of home environment. Markers, printers, and whiteboard are mandatory teaching and assessment tools for effective performance. The problems that are noticed while teaching from home are mainly related to, but not limited to, noise, music, visitors, household work and family interference that have adverse effect on teaching and assessment quality. Additionally, there are other discrepancies such as neighborhood clamor or family interruption during teaching. Therefore, teaching online through the internet has unpropitious negative influence. Teaching assessments and teaching pedagogies supported by in-person or through institution get affected through bad internet connectivity. To avoid such circumstances, a complete separated setup is required which is hustle free from external distraction and other family problems with basic facilities available to demonstrator without any financial worries. Another factor that can affect the teachers performance especially while going online medium is institutional support. Zoom, Skype, YouTube, Duo, Google Meet are the freely available platforms to the teachers.

Other paid options are available to the institutions which they give to teachers and class facilitators such as LMS, UMS, Moodle and google meet paid version. The institutions with good financial backing utilize paid forms of technologies without any delay and restriction. As matter of fact, due to good financial positions, many institutions already have license of software even before the start of pandemic Covid-19. The teachers of these institutions were well trained, technically well off with clarity of direction and purpose and had organizational support to deliver online classes and assessments for betterment of academia world. On the other hand, the institution that are weak in financial positions cannot afford licensed versions of online teaching technologies. Moreover, these institutions teachers are also lacking in proper training and technical assistance. The selection of platform for online teaching is not also easy for teachers due to their data issues, security, phishing attack and virus which may hinder teachers performance. Resultantly, they are apprehensive and unclear about teaching and assessing online. Moreover, it was found that the teacher with institutional support performed better as compared to teachers who didnt have support. Therefore, it can me concluded that institutional support makes teachers work easier, faster and hustle free.

\section{Conclusion}

It is obvious that online teaching classes cannot replace the conventional mode of teaching but pandemic has shown that the education system can be tech-savvy. The use of technology, even in conventional teaching, cannot be neglected and has an imperative role in teachers performance. This study undoubtedly portrayed the importance of technology supplemented with organizational support to make online teaching and assessment effective. To apply divine technology for teaching in virtual and real world, it is imperative to have a dedicated department that can facilitate the faculty with latest technologies usage. It will 
eventually help to build up organizational resource and technological infrastructure. To get in a separate league, training on LMS must be mandatory part of teachers role and it should be used for all educational purposes in the institute.

Pakistan has to equip its education sector with contemporary technologies as future belongs to technology-driven education system. In this regard, the current study has identified the major laps of technology that education system can get assistance especially in the developing world. The National Command Operation Center (NCOC) 2020 suggested HEIs of Pakistan to increase the scope of online teaching by inculcating new technologies for efficient lectures delivery. It was also decided with mutual consent of Higher Education Commission that all institutions will allocate special budget for technology upgradation and to train teachers. Eventually, the major part of this budget should be spent on getting access to technologies like online Ed-techs, LMS, Moodle, Microsoft teams, google meet for online teaching modes.

\subsection{Practice implication}

The findings of the study are pivotal for HEIs for facilitation and mechanisms. Moreover, this research is helpful for HEC to formulate an education system that can support institutions especially during any inevitable circumstances. Finally, this research is helpful for trainers and instructors who are planning to deliver sessions online. The potential barriers are also discussed in this study, which mentors should consider before teaching online and eventually provided some suggestion for assessment execution and online teaching. This study delivers a comprehensive review of enduring online education mode through the lock-down tenure entailing details on how quality of education was ensured through online teaching-learning process, E-portal access, self-reliant technological system, online assessment, quality standards.

\subsection{Suggestions}

Covid-19 has shattered economies and crippled the education sector globally. However, it has resulted in smart learning instead. It has encouraged education sector to adopt modern technologies, which has helped teachers to adopt modern teaching pedagogies and test them online. The teachers are advised to get institutional support as well as online mechanisms, which can help them to learn and use those technologies. Institutions are highly recommended to use technology-based infrastructure, which can facilitate teachers as well as students.

\subsubsection{Planning of higher education institutes}

The education institute should equip themselves with the latest technology to move forward. It will help teachers to deliver and assess lectures effectively and efficiently. They should also change the policy framework and stress on

Business Review: (2021) 16(2):44-59 
technology-based structure for better online delivery. Another addition during crisis should be to accept EdTech for successful facilitation of mentors and to implement new strategies. This implementation should be across the board instead of only in teaching field. The implementation of technology in administration will help students in assignments, presentations, attendance and other study activities.

\subsubsection{Teacher's self-development}

The pandemic results indicate that relationship between education sector and technology is long-term. Teachers are the main pillar of any education system and should be required to adapt through technology to facilitate students for long term. The study pointed out different problems faced by teachers during online teaching and assessment like separate room for teaching, noises, connectivity of internet and lack of training for online teaching and usage of LMS. The study suggests that teachers should proactively handle these situations and take support of institution without any delay. The institutional support in this perspective is needed especially in developing countries.

\subsubsection{Government support}

Government is the key component of HEIs. The internet connectivity and availability of technology infrastructure at macro level in the prime responsibility of government rather than individual institutes. Therefore, government attention is needed. The efficient way to resolve this issue is to establish a public private partnership to ensure uninterrupted supply of internet. HEIs also can facilitate government by providing latest Reseaerch and Development in this sector. In this way, a win-win situation can be created to reduce cost burden on government.

\subsubsection{Promoting sustainable development}

The major part of pollution was through paper work and printing, which is used in conventional teaching approaches. This pandemic situation pushed teachers to work on desktop and minimize printing and paper work. Assessments went online and saved major part of paper work that eventually contributed to environmental sustainability. However, authorities should ensure that this is a long lasting practice and should be part of policy to evaluate and assess online.

\subsubsection{Digital and hybrid model}

Developing UMS and LMS where teacher-students can interact is becoming essential for every university. It will help HEIs to maintain quality of education, and make evaluation and monitoring easy. Moreover, it will also eliminate the connectivity disruption problem of internet. Once the study material is uploaded, students can easily download it. 
Linking online business education and academic excellence:

\subsection{Limitation and future Scope}

Home environment and teaching and assessment were the main highlights of this research during Covid-19 lockdown in Pakistan. Since it was an unpredictable situation, it was quite hard to find literature especially in developing countries like Pakistan. Other limitation came to existence about methodology. This paper is based on interpretivism paradigms and therefore, accommodated a minute sample size. The respondents of this study were teachers but other stake holders of the institute should participate.

\section{References}

Adedoyin OB, Soykan E (2020) Covid-19 pandemic and online learning: the challenges and opportunities. Interactive Learning Environments pp 1-13

Adnan M, Anwar K (2020) Online learning amid the covid-19 pandemic: Students' perspectives. Online Submission 2(1):45-51

Alase A (2017) The interpretative phenomenological analysis (ipa): A guide to a good qualitative research approach. International Journal of Education and Literacy Studies 5(2):9-19

Alhumaid K, Ali S, Waheed A, Zahid E, Habes M (2020) Covid-19 \& elearning: Perceptions $\&$ attitudes of teachers towards e-learning acceptancein the developing countries. Multicultural Education 6(2):100-115

Aliyyah RR, Rachmadtullah R, Samsudin A, Syaodih E, Nurtanto M, Tambunan ARS, et al (2020) The perceptions of primary school teachers of online learning during the covid19 pandemic period: A case study in indonesia. Journal of Ethnic and Cultural Studies $7(2): 90-109$

Arora AK, Srinivasan R (2020) Impact of pandemic covid-19 on the teaching-learning process: A study of higher education teachers. Prabandhan: Indian journal of management $13(4): 43-56$

Baber H (2020) Determinants of students perceived learning outcome and satisfaction in online learning during the pandemic of covid-19. Journal of Education and e-Learning Research $7(3): 285-292$

Barnard Y, Bradley MD, Hodgson F, Lloyd AD (2013) Learning to use new technologies by older adults: Perceived difficulties, experimentation behaviour and usability. Computers in human behavior 29(4):1715-1724

Baticulon RE, Sy JJ, Alberto NRI, Baron MBC, Mabulay REC, Rizada LGT, Tiu CJS, Clarion CA, Reyes JCB (2021) Barriers to online learning in the time of covid-19: A national survey of medical students in the philippines. Medical science educator 31(2):615626

Cahen F, Borini FM (2020) International digital competence. Journal of International Management 26(1):100,691

Cucinotta D, Vanelli M (2020) Who declares covid-19 a pandemic. Acta Bio Medica: Atenei Parmensis 91(1):157

Doyumgaç I, Tanhan A, Kiymaz MS (2021) Understanding the most important facilitators and barriers for online education during covid-19 through online photovoice methodology. International Journal of Higher Education 10(1):166-190

Espino-Díaz L, Fernandez-Caminero G, Hernandez-Lloret CM, Gonzalez-Gonzalez H, AlvarezCastillo JL (2020) Analyzing the impact of covid-19 on education professionals. toward a paradigm shift: Ict and neuroeducation as a binomial of action. Sustainability 12(14):5646

Farooq F, Rathore FA, Mansoor SN (2020) Challenges of online medical education in pakistan during covid-19 pandemic. J Coll Physicians Surg Pak 30(6):67-9

Gujjar AA, Naoreen B, Saifi S, Bajwa MJ (2010) Teaching practice: Problems and issues in pakistan. International Online Journal of Educational Sciences 2(2)

Joshi A, Vinay M, Bhaskar P (2020) Impact of coronavirus pandemic on the indian education sector: perspectives of teachers on online teaching and assessments. Interactive Technology and Smart Education

Business Review: (2021) 16(2):44-59 
Khan IU, Hameed Z, Yu Y, Khan SU (2017) Assessing the determinants of flow experience in the adoption of learning management systems: the moderating role of perceived institutional support. Behaviour \& Information Technology 36(11):1162-1176

Mailizar A, Abdulsalam M, Suci B, et al (2020) Secondary school mathematics teachers' views on e-learning implementation barriers during the covid-19 pandemic: The case of indonesia. Eurasia Journal of Mathematics, Science \& Technology Education pp 1-9

Molise H, Dube B (2020) Emergency online teaching in economic and management sciences necessitated by the covid-19 pandemic: The need for healthy relations in a rural schooling context. International Journal of Learning, Teaching and Educational Research 19(6):387400

Nation M, Christens BD, Bess KD, Shinn M, Perkins DD, Speer PW (2020) Addressing the problems of urban education: An ecological systems perspective. Journal of Urban Affairs 42(5):715-730

Prottas DJ, Cleaver CM, Cooperstein D (2016) Assessing faculty attitudes towards online instruction: A motivational approach. Online Journal of Distance Learning Administration 19(4)

Rajab MH, Gazal AM, Alkattan K (2020) Challenges to online medical education during the covid-19 pandemic. Cureus 12(7)

Rizvi NF, Gulzar S, Nicholas W, Nkoroi B (2017) Barriers in adopting blended learning in a private university of pakistan and east africa: faculty members perspective. Mhealth 3

Scherer R, Siddiq F, Tondeur J (2019) The technology acceptance model (tam): A metaanalytic structural equation modeling approach to explaining teachers adoption of digital technology in education. Computers \& Education 128:13-35

Setiawan AR (2020) Scientific literacy worksheets for distance learning in the topic of coronavirus 2019 (covid-19). EdArXiv DOI: https://doi org/1035542/osf io/swjmk

Smith JA, Osborn M (2015) Interpretative phenomenological analysis as a useful methodology for research on the lived experience of pain. British journal of pain 9(1):41-42

Sun L, Tang Y, Zuo W (2020) Coronavirus pushes education online. Nature Materials 19(6):687-687

Sutherland WJ, Broad S, Caine J, Clout M, Dicks LV, Doran H, Entwistle AC, Fleishman E, Gibbons DW, Keim B, et al (2016) A horizon scan of global conservation issues for 2016 Trends in ecology \& evolution 31(1):44-53

Taylor JC (2002) Teaching and learning online: The workers, the lurkers and the shirkers. In: Proceedings of the 2nd Conference on Research in Distance and Adult Learning in Asia, Open University of Hong Kong, p 31

Wagman JB, Caputo SE, Stoffregen TA (2016) Hierarchical nesting of affordances in a tool use task. Journal of Experimental Psychology: Human Perception and Performance 42(10): 1627

Wang C, Wang D, Abbas J, Duan K, Mubeen R (2021) Global financial crisis, smart lockdown strategies, and the covid-19 spillover impacts: A global perspective implications from southeast asia. Frontiers in Psychiatry 12

Wu H, Niu D (2017) Study on influence factors of electric vehicles charging station location based on ism and fmicmac. Sustainability $9(4): 484$ 